\title{
A little-known aspect of Arthur Conan Doyle (1859-1930): the call of India and a debt to Walter Scott (1771-1832)
}

\author{
D L Gardner, M F Macnicol, P Endicott, D R T Rayner and P Geissler
}

\begin{abstract}
Summary: This paper recalls the early life of Dr Arthur Conan Doyle when his writing centred briefly on India. The significance of a young female skeleton given to the museum of the Royal College of Surgeons of Edinburgh in 1879 is reviewed. Morphometric and genetic evidence is provided to show that the skeleton originated in the Andaman Islands. It is suggested that Doyle saw it during his undergraduate or early postgraduate years, leading him to introduce an Andaman Islander into his novel The Sign of the Four, published in 1890. Like his inspiring predecessor Walter Scott, Doyle wrote of India but did not visit the country: both authors learned indirectly of the Indian Raj and the Indian Medical Service. Doyle knew of the convict colony established after the Sepoy Mutiny of 1857 at Port Blair, capital of the Andamans, but the reason he chose an Islander to commit murder in London has, until now, remained contentious.
\end{abstract}

The recent discovery of an Andamanese skeleton, brought to light from the attic of the museum of the Royal College of Surgeons of Edinburgh (RCSEd) has re-awakened interest in the question of why Dr Arthur Conan Doyle (Figure 1) selected an Andaman islander as a pivotal character in one of his best known stories, The Sign of the Four, a tale consolidating the position of Sherlock Holmes as a fictional detective gifted with remarkable powers of observation and deductive reasoning. ${ }^{1}$

The skeleton bears a card, loosely attached to the sternum, inscribed:

Skeleton of an Andamanese Woman, sent home from Port Blair and presented by Dr Brander F.R.C.S.Ed.

The skeleton is that of an adult female $137 \mathrm{~cm}$ (53.9 inches) in height. Around the neck hangs a

\footnotetext{
Dugald Gardner, ScD MD FRCP FRCSEd, is Conservator Emeritus of the Royal College of Surgeons of Edinburgh; Emeritus Professor of Histopathology of the University of Manchester; and Honorary Fellow of the College of Medicine and Veterinary Medicine, University of Edinburgh, Edinburgh, UK. He was Director of the Kennedy Institute of Rheumatology, London, and Musgrave Professor of Pathology of the Queen's University of Belfast. (email: dgardner@ staffmail.ed.ac.uk)

Malcolm Macnicol, MD MCh FRCSEd (Orth) FRCS FRCP, was Senior Consultant Orthopaedic Surgeon to the Royal Hospital for Sick Children, Edinburgh, UK. He was President of the British Orthopaedic Association and a Treasurer of the Royal College of Surgeons of Edinburgh, Edinburgh, UK.

Phillip Endicott BA (Archaeology and Anthropology), MA (University of East Anglia - Anthropology), MSc (Human Biology), is a PhD student of The Henry Wellcome Ancient Biomolecules Centre for Molecular Evolution, Department of Zoology, University of Oxford, Oxford, UK.

Daniel Rayner, BSc, is a $\mathrm{PhD}$ student of the Australian National University, Canberra ACT 0200, Australia. He is Lecturer in Forensic Medical Practices at the Canberra Institute of Technology.

Paul Geissler, DDS FDSRCSEd, is Curator of the Dental Museum of the Royal College of Surgeons of Edinburgh, Edinburgh, UK. He was Senior Lecturer and Consultant in Restorative Dentistry of the University of Edinburgh, President of the Royal Odonto-Chirurgical Society of Scotland and of the British Society for the Study of Prosthetic Dentistry.
}

necklace of ivory ringlets. The bones, secured by wire and suspended on a brass cylinder, are devoid of recognizable disease both anatomically and radiologically. The catalogue number is GC 2561.

A letter dated 15 October 1879 from Dr Brander accompanies the donation and explains that some phalangeal bones were lost during disinterment. With the exception of the right lower third molar, every tooth appears to have been present during life although several, displaced postmortem, are retained in a jar. The dental evidence (Figure 2) confirms that the individual was about 35 years old.

In order to be certain that the skeleton was in fact Andamanese, it was essential to test the ethnicity of the remains by both morphometric ${ }^{2}$ and genetic ${ }^{3}$ studies. These showed the identity of the individual to be consistent with an origin in the region of the Andamans that was under British control during the latter part of the nineteenth century (Figure 3).

\section{Discussion}

In every part of the world, students of Arthur Conan Doyle's writings and, in particular, those devotees of his fictional character Sherlock Holmes, are closely aware of Doyle's publication in 1890 of The Sign of the Four. ${ }^{4-6}$ In published editions, the form used for the title of the book depended on whether the text was taken from a magazine or from an authorized edition. The longer title The Sign of the Four was used in the 1993 Oxford Sherlock Holmes Collected Edition, edited by Professor OD Edwards. Christopher Roden, who wrote the Introduction to this edition, explained how Doyle himself used both forms. It was the tale that confirmed the role of the masterly investigator of crime. The Sign of the Four centred on a murder committed by a native of the Andaman Islands, Tonga, who had been brought to England by a revengeful former convict, Jonathan Small, intent on recovering the jewels taken from Agra 


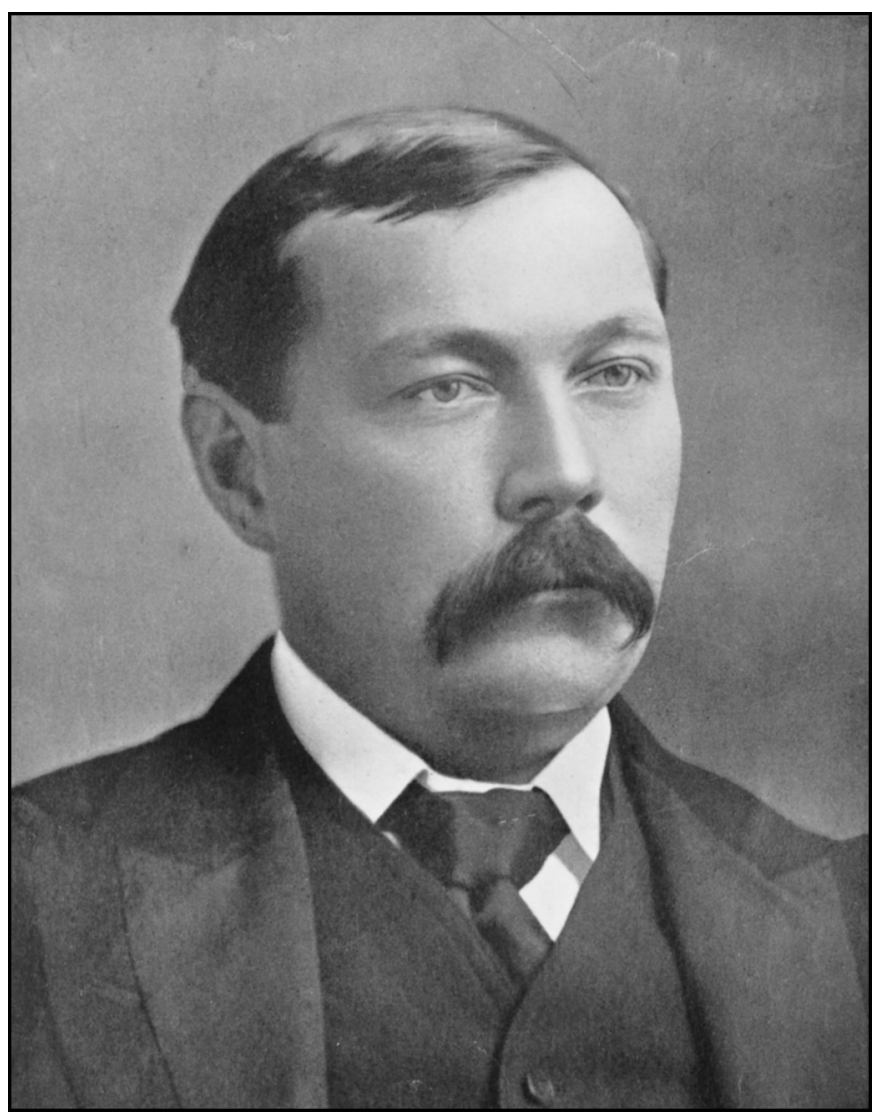

Figure 1 Arthur Ignatius Conan Doyle at the height of his early fame as an author (Reproduced courtesy of the Wellcome Library, London)

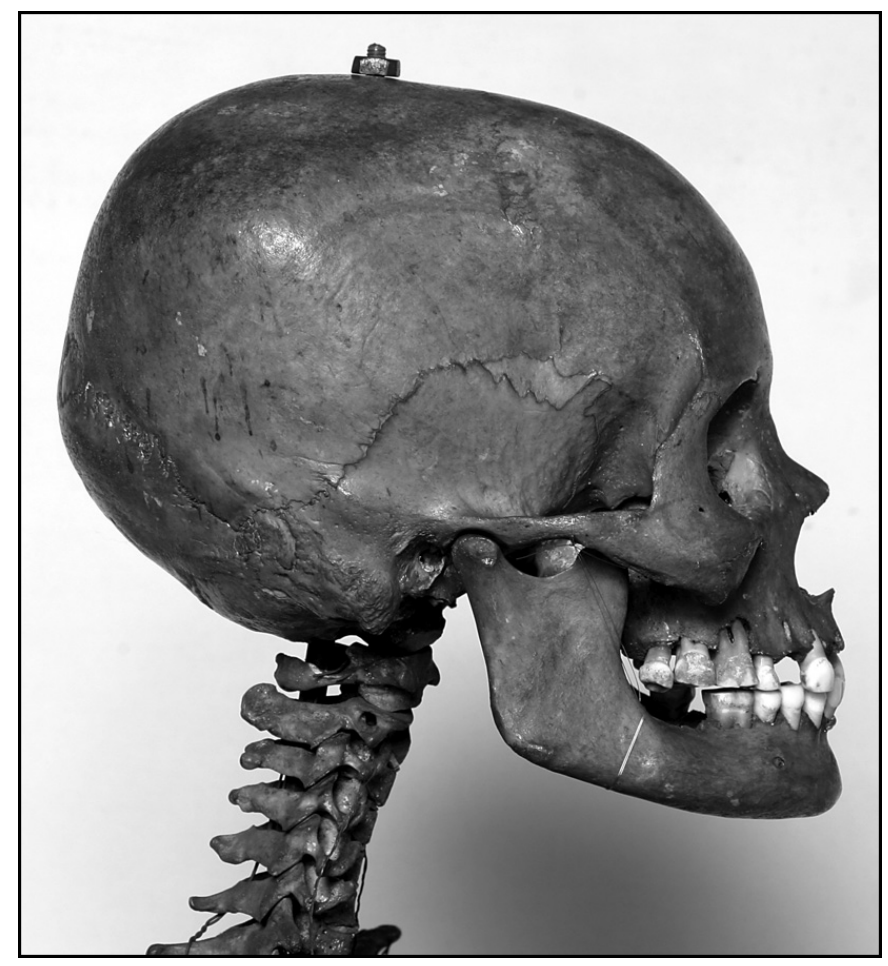

Figure 2 The dentition supports the evidence that the skeleton GC 2561 is that of a female aged approximately 35 years at the time of the Sepoy Mutiny in 1857. Small was the villain central to the plot, Tonga merely his tool.

Such is the interest in Conan Doyle's writings, in particular in those that describe the work of Sherlock Holmes, that new facts and theories continue to emerge after a century of literary and scientific research. It seems likely that Doyle introduced an Andaman islander as a character into his The Sign of the Four as a result of observing, in the RCSEd, an Andamanese skeleton presented to the College by Dr Brander in 1879. The presentation was made during the years (1876-81) when Doyle was a student of medicine in the University of Edinburgh and a clinical assistant to Joseph Bell (1837-1911), surgeon to the Royal Infirmary of Edinburgh.

Doyle openly acknowledged the debt he owed Bell on whose character and mannerisms he based many of those of Sherlock Holmes. Bell became surgeon to the Hospital for Sick Children in 1886, soon after Doyle was awarded the degree of MD. Bell was also Secretary and Treasurer of the RCSEd from 1876 and President of the College from 1887 until 1889. It is likely that he was aware of the donated skeleton - all museum acquisitions were reported to the President and Council and highly probable that he discussed it with his protégé. However, there is no mention of the donation in contemporary issues of the Edinburgh Medical Journal of which Bell was editor. A search of the journal for the period 1870-80 has not revealed mention of other acquisitions, although, of course, the receipt of publications and books was recorded.

\section{Conan Doyle and India}

The identity of the donor of the skeleton suggests an explanation for Doyle's familiarity with the archival material. It is possible that Brander and Doyle were friends or colleagues. There is no evidence to support this suggestion but it remains of interest to establish Brander's identity.

A search of the late nineteenth century papers of the Edinburgh Royal Colleges and of the Medical School of the University of Edinburgh for all those with this surname, and of the Records of the City of Edinburgh, reveals that the most likely individual was Dr Edward Salisbury Brander (1854-1902), born in India where his father, James Mainwaring Brander (1796-1856), served in the Indian Medical Service (IMS). Young Brander returned to Great Britain for his education and qualified LRCSEd, LRCPEd from the Extramural School of Medicine (ESM) of the Edinburgh Royal Colleges in July 1876 . He was registered to practise medicine on 23 December of that year; and graduated $\mathrm{MB}, \mathrm{CM}$ from the University of Edinburgh in 1877. He followed his father into the IMS and was part of the Khaibar Field Force during the Afghanistan campaign of 1879-80. It is relevant to note that Conan Doyle chose the disastrous Battle of Maiwand during the Second Afghan War of 1878-80 as the struggle in which Dr John Watson received the wound that invalided him out of the army. In A Study in Scarlet, Watson had been shot in 


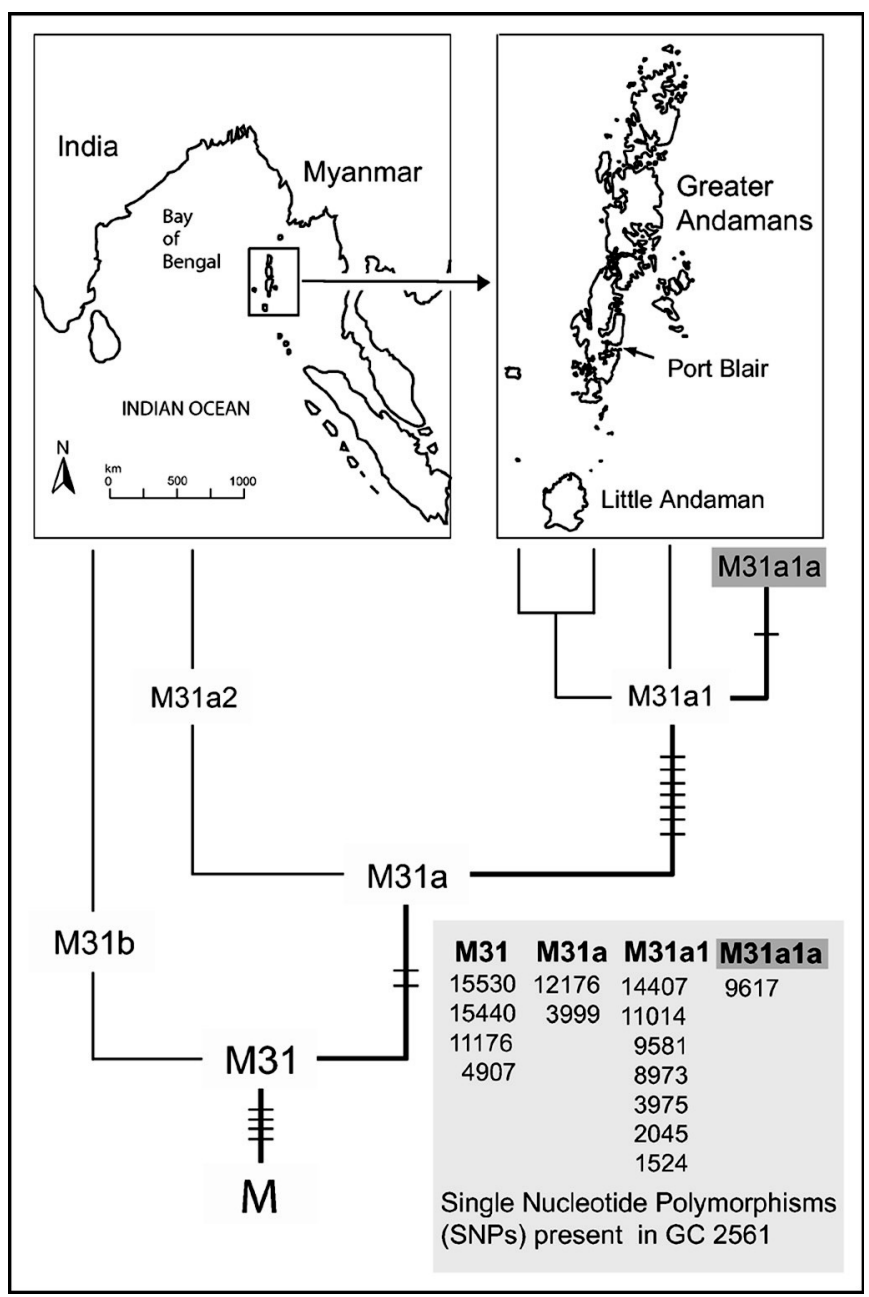

Figure 3 Phylogeographic tree of mtDNA haplogroup M31 found in South and Southeast Asia. The diagram highlights (bold) the single nuclear polymorphisms present in GC 2561. The mutations present in the DNA of the RCS skeleton indicate membership of M31a1 found only in the Andaman Islands

the shoulder but, in The Sign of the Four, Doyle described the wound as of the leg. In his Introduction to the 1993 Oxford Sherlock Holmes, OD Edwards suggests that Watson may have been wounded in several places, like Dr Bryden who alone survived the 1842 retreat from Kabul during the First Afghan War.

Elected a Fellow of the RCSEd on 3 July 1880, ES Brander continued as surgeon on the Bengal staff of the IMS and was the Second Medical Officer at Port Blair and Nicobar. He was there during the months in which Doyle was writing The Sign of the Four. Brander's address, Ranche Bengal, was recorded in the Medical Register and remained unchanged until his death.

\section{The East India Company}

It is no longer easy to recall the great part played by the Indian Raj in the life of Great Britain and Ireland. With the ending of the Empire in 1947, recruitment of British professional persons to the service of India and Pakistan fell away. However, in the eighteenth and nineteenth centuries many from Britain set out to make their fortune in the administrative and medical services of the Raj. It is no surprise therefore to find that the IMS played a part in the works of some of the greatest writers in the English language.

The reasons why the IMS was so influential may be found in its very long and distinguished history. ${ }^{7}$ In 1930 Crawford's volumes were complemented by a list of those who had served in the IMS before that date. ${ }^{8}$ The first fleet of the Association of Merchant Adventurers, formed in 1599, received a Royal Charter on 31 December 1600 and was incorporated as The Governor and Company of Merchants of London Trading with the East Indies, the East India Company. The establishment of the trading company was a final consequence of a longstanding dispute with the Dutch who had raised the price of pepper, against the English, in 1599. The origins of the IMS can be traced to this time since each of the 'foure tall ships' of the first fleet carried two surgeons and a barber. ${ }^{9}$

\section{Doyle's interest in the Andaman Islands}

The Andaman archipelago comprises 204 islands. In the years of the Raj, a capital was established at Port Blair, South Andaman. A penal colony was built in 1858 and here mutineers, held after the Sepoy Mutiny of 1857, were imprisoned. Although officers of the IMS provided medical care, the convicts' treatment was harsh.

Throughout the nineteenth century there was intense interest in the unusual phenotype of the inhabitants of the Islands. ${ }^{10}$ They were described as small in stature, with dark skin pigmentation and tight, curly hair. It was said, moreover, that they were hideous and deformed. Such prejudices, perpetuated by reports suggesting that shipwrecked seamen were murdered, ${ }^{11}$ were repeated in Doyle's novel.

With time and a better understanding of the Islanders, the fearsome reputation of the Andamanese gradually changed and by 1929 it was accepted that the small numbers of surviving Islanders were merry companions and keen sportsman, although it was said that they might be vindictive when angered. ${ }^{12}$ It may be concluded that Doyle's initial description of the assassin, Tonga, in his novel as a 'small, evil, black-haired, ape-like figure' owed much to contemporary writing. Despite his unwarranted assumptions, Doyle's account is balanced by his emphasis on the dwarf's loyalty towards Jonathan Small, the former convict who brought the Islander to England. Although the murderer, Tonga's actions seem to have been a misrepresentation of Small's intentions.

A further plausible explanation for Doyle's interest in and understanding of the Indian Raj was his association, during his years in Southsea, with Major General Alfred Wilks Drayson (1827-1901), ${ }^{13}$ a near neighbour, patient and mentor. Drayson was an artilleryman who had served in the army in the Bengal Presidency and inspected army forts, including that at Agra, on behalf of the Government. Another individual who had already influenced Doyle in many ways and who might 
have drawn his attention to the Andaman skeleton was Bryan Charles Waller (1853-1932), ${ }^{14}$ Doyle's patron and literary advisor who was resident with Doyle's parents and family. Waller qualified LRCSEd, LRCPEd in 1875, the year before ES Brander, and graduated $\mathrm{MB}, \mathrm{CM}$ in 1876, proceeding MD with Honours in 1878. Waller taught pathology, morbid anatomy and practical pathology in the ESM, and pathological histology in the Minto House School, Edinburgh. Because of his professional interest in pathology and his familiarity with the RCSEd, it is highly likely that he knew of the Andamanese skeleton. He may have transmitted this interest to his younger friend Doyle.

An additional reason for Doyle's fascination with the Andaman Islands may have been the death of the Viceroy of India, Lord Mayo (1822-72). The Viceroy, like Doyle's paternal grandfather, was Irish. Lord Mayo was assassinated while on a visit to the Islands in 1872. It is probable that this vile act that took place in a disturbed community and was perpetrated by an Afghan convict who had been incarcerated for an earlier murder, caught the attention of the Jesuits with whom Doyle was then in residence as a schoolboy at Stonyhurst College in Lancashire. His teachers laid a particular emphasis on military and colonial careers and were deeply interested in the prospects for pupils whose fathers were members of these professions. The murder of the Viceroy almost certainly came to the attention of the Doyle family themselves.

An even more likely link between Doyle's writing and the IMS was the appointment in 1885 of Sir William Muir $(1819-1905)^{15}$ as Principal of the University of Edinburgh. Muir, a colleague of Lord Mayo, had been one of three administrators controlling the fort at Agra when it became a refuge for the British during the Mutiny. Muir returned to Britain in 1876. In July 1885 Doyle was awarded the MD. During the graduation ceremony he may have heard Muir's inaugural address for, as Roden ${ }^{16}$ comments, 'Muir was the most accessible Principal that students had known in living memory'. It is probable Muir and Doyle conversed: Doyle was one of the few receiving a medical doctorate in that year and Muir could have been another source for Doyle's vivid descriptions of Agra.

\section{Walter Scott and India}

A fascination with Indian life and culture was an important stimulus not only to Conan Doyle but to other eminent nineteenth century authors, in particular Walter Scott (1771-1832). ${ }^{17}$ Ever since reading all Scott's works as a schoolboy, Doyle had regarded him as his chief source of inspiration. The rich and fantastic tapestry depicted in Scott's accounts of the life of the princes and religious leaders of Madras and their political intrigues were given in the later chapters of his short novel The Surgeon's Daughter ${ }^{18}$ set in the middle of the eighteenth century. The scenes portrayed by Scott were, he conceded, devised from the descriptions given to him by his friend and neighbour, James Ferguson (1778-1859) whose name he concealed in its
Gaelic form as Colonel Mackerris or MacErries, 'one of the best fellows who ever trode a Highland moor, or dived into an Indian jungle'. In the early part of the novel Scott offered a penetrating insight into Scottish medical practices of the time. In the pursuit of fame and fortune, ambitious young men, including medically qualified individuals, sought to join the East India Company and among them were many Edinburgh medical graduates and diplomates.

In addition to the recruitment of young men from the professional classes and from impecunious nobility, particularly when uprisings and rebellion threatened the Company's trade, drastic steps were taken to 'pressgang' indigent and poor persons. Scott graphically described the conditions under which unscrupulous East India Company officers abused them. Among these tales was an explicit account of the conditions in a military hospital in the Isle of Wight (the name of the hospital is not given by Scott but it was near Ryde). In his inimitable style, Scott described the appalling treatment of those incarcerated amid the threat of epidemic smallpox. Well aware of the new practice of inoculation that was beginning to be used, Scott's Adam Hartley avoided placing smallpox victims in heated rooms with blankets and spiced wines, and instead achieved success by opening windows and replacing wine with cooling drinks.

In 1809 Scott was confronted by the consequences of a long drawn-out bickering with his publisher, Archibald Constable and his partner, Alexander Gibson Hunter. Scott decided to be his own publisher. Soliciting the assistance of John Murray and London friends, he established the firm of John Ballantyne and Company. James Ballantyne was essentially a printer with no understanding of commerce and money; his irresponsible brother John compounded the difficulties. Scott soon faced the folly of supporting James Ballantyne financially. The publishing accounts were in unsafe hands. Confronted with bankruptcy, Scott dreaded the consequences of the company's misplaced optimism.

In 1810 Scott wrote 'in confidence' to his younger brother Thomas (Tom) to say that he was contemplating an entire change of life and that if Robert Dundas (1742-1811), Lord Melville, were sent out to India as Governor-General and offered him a good post, he would not hesitate 'to pitch the Courts of Session and the Booksellers to the Devil and try my fortune in another climate' ${ }^{19,20}$ However, Scott did not travel to India. Lord Melville died in 1811 and the prospects of making a fortune in an eastern land were set aside.

\section{Walter Scott's influence on Conan Doyle}

Just as Scott had taken advantage of his understanding of India in The Surgeon's Daughter, ${ }^{21}$ so Doyle exploited his acquired knowledge of Indian affairs to develop the plot of The Sign of the Four.

Doyle knew of Bengal from an early age and mentioned the province during his adolescent preoccupation with the writings of Thomas Macaulay ${ }^{22}(1800-59)$. 
By 1889 he was already an inveterate traveller but he had not visited India and did not have an opportunity to observe the Andamanese in their homelands. It must be assumed that in The Sign of the Four he made use of contemporary accounts of these unusual people. Doyle would have become familiar with Scott's The Surgeon's Daughter shortly before or soon after the assassination of Lord Mayo. Scott's remarkable understanding of the East India Company and its surgeons, like that of Doyle, was gained second-hand. In the minds of both authors India was associated with an exotic career ending in a crime of violence of the kind exemplified by The Sign of the Four.

Acknowledgements: We thank the President and Council of the Royal College of Surgeons of Edinburgh for permission to reproduce archival material from the College collections and Mr Pradip Datta FRCSEd, Professor Owen Dudley Edwards and $\mathrm{Mr}$ Iain Macintyre FRCSEd for their critical comments. Phillip Endicott was supported by the Natural Environment Research Council and by Magdalen College, Oxford, UK. Daniel Rayner was in part supported by the Australian Research Council Discovery project The Contribution of South Asia to the Peopling of Australasia. The skilled assistance of Mark Baillie, Andrew Connell, Sheena Jones, Steven Kerr, Max McKenzie, Andrew Morgan, Marianne Smith and the late David Wilson is gratefully acknowledged.

\section{References and notes}

1 Roden C. Introduction to Arthur Conan Doyle's The Sign of the Four. In: Owen Dudley Edwards, ed. The Oxford Sherlock Holmes. Oxford, England; New York: Oxford University Press, 1993

2 In a morphometric investigation, the 47 linear cranial measurements used by Howells were first recorded. Discriminate functions analysis (DFA), a form of multivariate analysis, permitted a comparison between the results and those in a world craniometric data-set comprising 349 individuals from eight populations, including the Andamanese. Seven of these populations were selected from within or near South East Asia; the eighth (Norse) was sufficiently distant to constitute an acceptable 'outgroup'. The results indicate that GC 2561 belongs with the Andaman Islander population included in this study (posterior probability 0.654 ). The probability that the present specimen is integral to the second most likely group, the Bushmen, is not significant (posterior probability 0.000). Howells WW. Cranial variation in man: a study by multivariate analysis of patterns of differences among recent human populations. Papers of the Peabody Museum of Archeology and Ethnology. Cambridge, MA:
Peabody Museum 1973;67:31-6; Howells WW. Howell's craniometric data on the internet. American Journal of Physical Anthropology 1996;101:441-2

3 In a second enquiry, genetic studies made by an examination of $30 \mathrm{mg}$ of dentine centred on a search for the 20 variable coding region sites that define the mtDNA lineages M31 and M32 characteristic of the Andamanese. The results (Figure 3) show that the skeleton is part of the Andaman-specific clade M31a1 by virtue of having the derived state at all 13 variable positions that distinguish this clade from the root of Asian haplogroup M. A mutation at $\mathrm{np} 9617$ further limits it to membership of a branch (M31a1a) specific to the Greater Andamanese rather than to their neighbours, the Jarawa. Endicott P, Metspalu M, Stringer C, Macaulay V, Cooper A, Sanchez JJ. Multiplexed SNP typing of ancient DNA clarifies the origin of Andaman mtDNA haplogroups amongst South Asian tribal populations. PLoS ONE 2006;1:e81 (DOI:10.1371/journal.pone.0000081)

4 Carr JD. The Life of Sir Arthur Conan Doyle. London: John Murray, 1949

5 Edwards OD. The Quest for Sherlock Holmes. A Biographical Study of Arthur Conan Doyle. Edinburgh: Mainstream, 1983

6 Stashower D. Teller of Tales. The Life of Arthur Conan Doyle. London: Allen Lane: the Penguin Press, 1999

7 Crawford DG. A History of the Indian Medical Service 1600-1913. London: W. Thacker \& Co; Calcutta \& Simla: Thacker Spink \& Co 1914; I:1-529; II:1-535

8 Crawford DG. Roll of the Indian Medical Service 1615-1930. London: W Thacker \& Co, 1930

9 McDonald D. Surgeons Two and a Barber. Being Some Account of the Life and Work of the Indian Medical Service (1600-1947). London: Heinemann, 1950

10 Andaman Islands. Encyclopaedia Britannica. 9th edn. Edinburgh: Adam \& Charles Black, 1875;1:11-13

11 Man EH. On the Aboriginal Inhabitants of the Andaman Islands. London: Trubner, 1883

12 Andaman Islands. The Encyclopaedia Britannica. 14th edn. London: The Encyclopaedia Britannica Company Ltd, 1929;1:895-7

13 Drayson AW. Experiences of a Woolwich Professor during Fifteen Years at the Royal Military Academy. London: Chapman \& Hall, 1886

14 Edwards OD. (loc. cit. ref. 5): p. 88

15 Powell AA. Sir William Muir (1819-1905). Oxford Dictionary of National Biography. Oxford: Oxford University Press, 2004;39:679-81

16 Roden C. (loc. cit. ref. 1): p. xix

17 Buchan J. Sir Walter Scott. London, Toronto, Melbourne, Sydney: Cassell, 1932

18 Scott W. The Surgeon's Daughter; Castle Dangerous and Glossary (part of the second series of Chronicles of the Canongate, 1827) London, New York: George Routledge \& Sons, 1831 (new edition)

19 Buchan J. (loc. cit. ref. 17): p. 100

20 Oman C. The Wizard of the North. The Life of Sir Walter Scott. London, Sydney, Auckland, Toronto: Hodder and Stoughton, 1973

21 Scott W. (loc. cit. ref. 18): p. 111-52

22 Thomas Babington Macaulay, first Baron Macaulay of Ruthven, was a distinguished English essayist and historian whose major work was his unfinished five-volume History of England from the Accession of James II (1848-61) 
